\title{
Challenges of poultry production in Nigeria: A review
}

Anosike, F. U., Rekwot, G. Z., Owoshagba, O. B., Ahmed, S. and Atiku, J. A. Livestock Systems Research Programme, National Animal Production Research Institute Ahmadu Bello University, Zaria, P.M.B 1096, Shika, Zaria. Nigeria

Corresponding Author: anosikefrancisugo@gmail.com; +2348038192350

\begin{abstract}
This study provides a review on the challenges facing poultry production in Nigeria and the possible solution. The study considered the socio-economic roles of poultry to include; means of livelihood and a way of achieving a certain level of economic independence, meeting human needs for dietary animal protein supply, source of foreign earnings and opportunities for saving, investment and security against risks for small-scale poultry farmers. This paper reviewed the challenges of poultry production in Nigeria and how the rate of production in the industry has slowed down. These challenges included; high rate of disease and pest attack, lack of loan and credit procurement, lack of technical knowledge, high rate of mortality, high cost of poultry feed, supply of poor quality chicks, inadequate poultry extension services, and inadequate access to and high cost of veterinary services, as reported by Possible solutions to these challenges are not farfetched, which included; intervention of veterinary in order to cub losses due to diseases, technical know-how for improving production should be made available to poultry keepers through extension service, poultry farmers should be encouraged to form cooperative societies or join existing one to be able to access loan for their business and addressing these challenges will prove vital to increase production, increase animal protein availability and consumption, and reduce the rate offood insecurity.
\end{abstract}

Keywords: poultry, livestock, production, challenges

\section{Introduction}

Nigerian economy, although has been largely depend significantly on the oil sector, Agriculture remains its mainstay. Agriculture contributed 24\% of Nigeria's gross domestic product (GDP) in 2008 (N $\mathrm{BS}, 2010)$. Agriculture is the second largest export earner after crude oil and employing over $70 \%$ of rural labour; thus, the sector ranks as a key contributor to wealth creation and poverty reduction (Nwafor, 2008). Nigeria's agricultural sector comprises four sub-sectors: crops, livestock, fisheries and forestry (Rekwot et al., 2015). Crops contribute about $85 \%$ to agricultural GDP, livestock production about $10 \%$, fisheries and Forestry about 4\% and 1\%, respectively in 2006 (Rekwot et al., 2015). The crop and livestock sub-sectors have maintained their shares in recent years, while the fishery has been expanding and the forestry shrinking (Nigeria vision 2020, 2009). In Nigeria, the major source of animal protein is the livestock industry. Over the years, the contributions of the livestock sub sector to Gross Domestic Product (GDP) have decreased from 5.61\% in 1960 to about $2.64 \%$ in 2010 (CBN, 2010). The contributions of livestock to Agriculture in 1999 and 2010 remain at $2.64 \%$ (CBN, 2010). Livestock production constitutes an important component of the agricultural economy in developing countries and it is an instrument of socio economic change, improved income and quality of rural life in Nigeria (Okumadewa, 1999). Poultry, as an aspect of livestock production outnumbers all 
other forms of livestock in Nigeria and not surprisingly is found throughout the country (Adeyemo and Onikoyi, 2012). Today, poultry production has developed from backyard business to a commercially oriented industry. Its offer of highest turnover rate and quick returns to investment outlay in the livestock enterprises has made it unique (Adeyemo and Onikoyi, 2012). In (FDLPC, 2004) reported that Nigeria produced 2 billion eggs, 12,000 tones of poultry meat, while estimated poultry meat consumption per capital was 1.3 Kilograms (Okaiyeto and Adamu, 2004). Poultry, which is next to ruminant as a source of protein in Nigeria, accounts for almost $25 \%$ of local meat production (Nwagu, 2002). The poultry sector is characterized by relative faster growth in consumption and trade volume than many other agricultural livestock sector. Different species in poultry production include; Chickens (local chickens, broilers, and layers), turkeys, geese, ducks, guinea fowls and pigeons. Despite the fast growing trade and importance of poultry production in Nigeria, it's not without challenges. This paper seeks to review the challenges of poultry production in Nigeria and suggest possible solution to cub these challenges to increase production, increase animal protein availability and consumption, and reduce the rate of food insecurity. The tables below shows that of all the livestock reared in Nigeria, chickens are the most populated, common and widespread, while Nigeria has the least rate of consumption of meat and egg, that is.8.1 and $3.5 \mathrm{~kg}$, respectively (Adeyemo and Onikoyi, 2012).

Table 1: Nigerian livestock population

\begin{tabular}{|c|c|c|}
\hline \multicolumn{2}{|l|}{ Species } & Number \\
\hline \multicolumn{2}{|l|}{ Chickens } & $82,400,000$ \\
\hline \multicolumn{2}{|l|}{ Goats } & $34,500,000$ \\
\hline \multicolumn{2}{|l|}{ Sheep } & $22,100,000$ \\
\hline \multicolumn{2}{|l|}{ Cattle } & $13,900,000$ \\
\hline \multicolumn{2}{|l|}{ Donkeys } & 900,000 \\
\hline \multicolumn{2}{|l|}{ Horses } & 200,000 \\
\hline \multicolumn{2}{|l|}{ Camels } & 90,000 \\
\hline \multicolumn{2}{|l|}{ Other poultry* } & $31,900,000$ \\
\hline \multicolumn{2}{|l|}{ Pigs } & $3,500,000$ \\
\hline \multicolumn{2}{|l|}{ Dogs } & $4,500,000$ \\
\hline \multicolumn{2}{|l|}{ Cats } & $3,300,000$ \\
\hline \multicolumn{2}{|l|}{ Rabbits } & $1,700,000$ \\
\hline \multicolumn{2}{|l|}{ Guinea pigs } & 500,000 \\
\hline \multicolumn{2}{|l|}{ Giant rats } & 60,000 \\
\hline \multicolumn{3}{|c|}{ *include pigeons, ducks, Guinea fowl and turkey; FAO Corporate Document Repository in 2010.} \\
\hline Country & Meat & Egg \\
\hline USA & 124.0 & 14.5 \\
\hline Spain & 113.1 & 13.9 \\
\hline Canada & 101.1 & 10.8 \\
\hline France & 99.9 & 16.0 \\
\hline Malaysia & 54.0 & 14.4 \\
\hline Japan & 42.4 & 19.2 \\
\hline Britain & 76.3 & 9.2 \\
\hline South Africa & 33.2 & 6.3 \\
\hline Libya & 32.7 & 9.4 \\
\hline Israel & 68.3 & 11.9 \\
\hline Tunisia & 23.9 & 7.3 \\
\hline Zambia & 11.0 & 3.9 \\
\hline Egypt & 22.6 & 2.1 \\
\hline Sudan & 21.1 & 1.2 \\
\hline Nigeria & 8.1 & 3.5 \\
\hline Algeria & 18.7 & 3.5 \\
\hline Morocco & 18.5 & 5.2 \\
\hline Chad & 15.4 & 0.5 \\
\hline Cameroon & 15.1 & 0.7 \\
\hline World average & 37.9 & 8.0 \\
\hline
\end{tabular}


Socio-economic Role of Poultry Production

Poultry production is one of the important components of the livestock subsector in the Nigerian economy, which can be embarked upon by the people with small or no land capital (Conroy, 2005). Nigeria's poultry industry is composed of local unimproved breeds and the high performing commercial breeds. Over the last 50 years, the exotic breed has made an aggressive incursion into the production economy of the country, while the local chicken is driven by traditional system management, the exotic breeds have stimulated an industrial advancement of the poultry industry through specialization as egg or meat type strains to satisfy the increasing demand for poultry commodity in the food market (Rekwot et al., 2015). It provides direct employment for a large number of rural and urban people and indirect employment to suppliers of products and services such as grain farmers, feed mill operators as well as those producing various goods and services used to support poultry production and marketing activities (Adeyemo and Onikoyi, 2012). Poultry is considered to be a means of livelihood and a way of achieving a certain level of economic independence in Nigeria. The primary purpose for keeping poultry in all parts of the country is for both dietary and economic reasons (Ogundipe and Sanni, 2002). Poultry as an aspect of livestock production is important to the biological needs, economic and social development of the people in any nation (Oladeebo and Ambe-Lamidi, 2007). However, the contribution of poultry production (meat and eggs) to total livestock output increased from $26 \%$ in 1995 to $27 \%$ in 1999 with an increase in egg production alone accounting for about $13 \%$ during the period
(Ojo, 2003). The development of the poultry industry has also been described as the fastest means of bridging the protein deficiency gap prevailing in most of the developing countries. The poultry industry, if properly harnessed can also serve as a source of foreign earnings complementing crude oil which at present constitutes the main source of foreign earnings in Nigeria (The - poultry site news 2009). In poultry production, small scale poultry production represents one of the few opportunities for saving, investment and security against risks. It accounts for approximately $90 \%$ of total poultry production (Branckaert, 1999). Poultry production in rural parts of the country is more important because of the divergent roles it plays (Nwagu, 2002). Poultry meat and eggs offers considerable potential for meeting human needs for dietary animal supply (Folorunsho and Onibi, 2005). This single reason among others has made the enterprise attractive and popular among small medium, as well as large scale poultry farmers

Challenges of poultry production in Nigeria

Despite the leading role of poultry production in the livestock industry, it's not without challenges. The challenges of poultry production in Nigeria cannot be over emphasized. These challenges have slowed down the rate of production in the industry. High rate of disease and pest attack as a major challenge in poultry production was reported by Ajala et al. (2007) and Aromolaran et al. (2013). Lack of access to Loan and credit procurement was also identified in different research carried out (Agbato, 1997; Akeeb 1997; Adebayo and Adeola, 2005; Aromolaran, 2013). Lack of technical knowledge was also reported by Olaniyi et al. (2008), and Aromolaran et al. (2013) as another challenge facing the industry, this they say, 


\section{Challenges of poultry production in Nigeria: A review}

that most people go into poultry farming simply because of the huge profit they see others getting, but fail to enquire the necessary knowledge involved in poultry production. High rate of mortality was also identified by Chilate and Guta (2001); Aromolaran (2013); Anosike et al. (2015), as major challenges facing the industry, this they say was due to supply of poor quality chicks as reported by Ajala et al. (2007); Adeyemo and Onikoyi (2012); Anosike et al. (2015). Anosike et al. (2015), also reported that most farmers do not have an idea of the farms that hatch the chicks they buy, as they buy from road side hawker. Ajala et al. (2007), also reported that mortality mostly occur at brooding stage. High cost of poultry feeds was identified by Agro-Ind (2002); Sonaiya and Swan (2004); Adeyemo and Adeyemo (2009). Adeyemo and Onikoyi (2012) reported that inadequate poultry extension services are one of the major challenges faced by the poultry industry. Inadequate access to and high cost of Veterinary services was reported by Adeyemo and Onikoyi (2012); Anosike et al. (2015) as another major challenge posing a trait to the industry.

\section{Possible solutions to the challenges of poultry production in Nigeria}

Despite the challenges of poultry production in Nigeria, it has not stopped the industry from functioning, though these challenges might have slowed down its production rate. Solution to cub these challenges are not farfetched. The incidence of diseases outbreak is one of the pressing challenge of poultry production in Nigeria. There is need for veterinary intervention in order to cub losses due to disease as suggested by (Ajala et al., 2007). Also educations on feeding of brood and simple disease control programmes are possible short-term methods to improve poultry production in Nigeria. Technical know-how for improving poultry production should be made available to poultry keepers through extension service. Thus the extension workers have a major role to play in improving rural poultry production as suggested by (Ajala et al., 2007). Aromolaran et al. (2013), in their research carried out in Ibadan, Oyo State on small poultry farms did recommended, that small scale layer poultry famers should be encouraged to form cooperative societies or join the existing one to be able to access loan for their business and government could also make fund available to assist the poultry farmers. They also recommended capacity training of poultry famers to enable them cope with the challenges of modern poultry farming and commercialization of small scale layer poultry production should be carried out. This is also in line with the recommendation of Adeyemo and Onikoyi (2012), who recommended that Government should provide financial assistance to subsistence and small-scale poultry farmers in form of soft loans. This they say will help to prevent the decline of the sectors as a result of unprofitable operation or increase in the price of its products. Anosike, et al. (2015) did recommend that to reduce the rate mortality to a barest minimum, hatchery industry should be inspected by relevant agencies to ensure that healthy day old chicks are produced under good hygiene condition.

\section{Conclusion}

The challenges of poultry production in Nigeria are multifaceted. These challenges might not have stopped the industry from functioning because there has been a steady increase in the demand for poultry products in Nigeria due to several factors such as increase in population, new poultry farms the expansion of existing ones and the resuscitation of some others which had 
stopped production but might has slowed down rate of production in the industry. This paper reviews this challenges to include; disease and pest attack, lackof loan and credit procument, lack of technical knowleged, high rate of mortality, high cost of poultry feed, supply of poor quality chicks, inadequate extension services, and inadequate access to and high cost of veterinary service. Possible solution to these challenges include; intervention of veterinary in order to cub losses due to diseases, technical know-how for improving production should be made available to poultry keepers through extension service, poultry farmers should be encouraged to form cooperative societies or join existing one to be able to access loan for their business and Government could also make funds available to assist the poultry farmers through soft loans, capacity training of poultry farmers to enable them cope with challenges of modern poultry farming etc. If the solutions stated above are set in place to tackle the challenges facing the industry, poultry industry is and will still remain one of the fastest growing livestock industry of the agricultural sector in the country.

\section{References}

Adebayo, O. O. and Adeola, R. G. 2005. Socio-economic factors affecting Poultry farmers in $\quad \mathrm{E} \mathrm{j} \mathrm{i} \mathrm{b} \mathrm{o}$ Local Government Area of Osun State, Nigeria. Journal of Human Ecology 18 (1):A39-41

Adeyemo, A. A. and Adeyemo, F. T. 2007. Problem militating against c o m m e r c a 1 e $\mathrm{g} g$ production in the southern Guinea Savannah of Nigeria Proceedings of the Annual Conference of Animal Science of Nigeria September $14-17^{\text {th }}, 2009$
LAUTECH, Ogbomosho, Nigeria $\mathrm{Pp}, 304$

Adeyemo, A. A. and Onikoyi, M. P. 2012. Prospects and Challenges of Large Scale Commercial poultry production in Nigeria: Agricultural Journal (7); 388-393. 20012.

Agbato, O. A. 1997. Effective Strategies for Egg marketing in Nigeria. Paper presented at A Workshop Organized by The Nigerian Society for Animal Production (NSAP), Ogun State. Nigeria.

Agro-Ind, 2002. European Union-West Africa Agro-Business Sector $\mathrm{m}$ e e $\mathrm{t}$ i n g: S t r a t e g i c evaluation of the Agro-Industrial Sector. Dakar, Senegal.

Ajala, M. K., Nwagu, B. I. and Otchere, E. O. 2007. Socio-economic of Free-Range poultry production Among Agro pastoral Women in Giwa Local Government Area of Kaduna State. $N i g$ e $r$ i a Veterinary Journal Vol.28 (3) 2007: 11-18

Akeeb, S. 1997. Problems of Poultry Production I n Nigeria. Paper Presented at a Workshop, Organized by The Nigeria Society for Animal Production (NSAP), Ogun State, Nigeria.

Anosike, F. U., Naanpose, C. D., Rekwot, G. Z., Sani, A., Owoshagba, O. B. and Madziga, I. I. 2015. Challenges of small-holder poultry farmers in Chikun Local Government Area of Kaduna State Nigeria. Proceedings of the $20^{\text {th }}$ Annual conference of the Animal Science Association of Nigeria 6$10^{\text {th }}$ September, 2015, University Ibadan, Oyo State. Pp. 302306

Aromolaran, A. K., Ademiluyi, I. O. and 
Itebu, O. J. 2013. Challenges of Small Poultry Farmers in Layers Production in Ibadan, Oyo State Nigerian. Global journal of science Frontier Research. 13:2:1

Branckaet, 1999. "Constraints in Poultry Production among Smallholder" Journal of Agricultural Science, 38, 387-399.

Central Bank of Nigeria 2010. Central Bank of Nigeria. Annual Report Statement of Account Statistical Bulletin

Chitate, F. and Guta, M. 2001 Country Report: Zimbabwe. In SADC Planning Workshop on New-castle Disease Control in Village Chickens. (Alders R.G and Spradow P.B Editors) proceedings 103. Aciar Canberra, Australia. Pp 46-50

FAO, 2012. Food and Agricultural Organization Corporate Document Repository in 2010

FAOSTAT, 2002 FAO Statistical Databases (CD-ROM). Food and Agriculture Organization of the United Nations, Rome, Italy

Federal Department of Livestock and Pest Control 2004. Unpublished Report: Livestock Population, Production, Consumption and Diseases control. FMARD, Gariki, Abuja. 2004

Folorunsho, O. R. and Onibi, G. B. 2005. Assessment of the Nutritional Quality of Eviscerated $\mathrm{W}$ a s t e from Selected Chicken Types. In Proceedings of the $1^{\text {st }}$ Annual Conference on Developments in Agriculture and Biological Sciences, 27 ${ }^{\text {th }}$ April, 2005 School of Agriculture and Agricultural Technology, Federal University of Technology, Akure, Nigeria.
Pp: 300 .

National Bureau of Statistic, 2010. Gross Domestic Product for Nigeria (Expenditure \& Income) NBS, Plot 762, Independence Avenue, Central Business District, Abuja.

Nwafor M. 2008. Literature review of development target in Nigeria. Ibadan: International Institute Tropical Agriculture.

Nwagu, B. I. 2002. Production and Management of Indigenous Poultry Species. Poultry Production in Nigeria. A Training Manual Pp 10-26. National Animal Production Research Institute, Federal Ministry of Agriculture and Rural Development. Ahmadu Bello University, Zaria, Nigeria

Ogundipe, S. O. and Sanni, S. A. 2002. Economic of Poultry Production in Nigeria. Poultry Production in Nigeria, A Training Manual Pp 2845 of the National Animal Production Research Institute, Federal Ministry of Agriculture and Rural Development. Ahmadu Bello University, Zaria, Nigeria.

Ojo, S. O. 2003. Production and Technical Efficiency of Poultry Egg Production in Nigeria. International Journal of Poultry Science, 2: 459-464

Okaiyeto, P. O. and Adamu, A. M. 2004. Export Potential of Livestock Product. A paper presented at the 3day National Workshop on Repositioning Nigeria Agriculture for

Export: Prospects and Challenges. Organized by ARMTI and NPASH. Ilorin, Octo ber 5-7, 2004.

Oladeebo, J. O. and Ambe-Lamidi, A. I. 2007. Profitability, Input Elasticity and Economic Efficiency of 
Poultry Production among Youth Farmers in Osun State, Nigeria. International Journal of Poultry Science 6(12): 994 - 998.

Olanyi, O. A. Adesiyan, I. O. and Ayoade, R. A. 2008. Constaints to Utilization of Poultry Production Technology among Farmers in Oyo State, Nigeria. Journal of Human Ecology 24(4): 305-309 (2008).

Rekwot, G. Z. Ahmed, S. and Dawang, N.

C. 2015. Technical efficiency of poultry egg production in Kaduna State, Nigeria. Proceedings of the $20^{\text {th }}$ Annual conference of the Animal Science Association of Nigeria, 6-10 $0^{\text {th }}$ September 2015, University of Ibadan, Oyo State. Pp 324-329.
Sonaiya, E. B. and Swan, S. E. J. 2004. Small-Scale Poultry Production. Technical Guide. FAO A nimal Production and Health Manual 1, Rome, Italy.

Received:11 $1^{\text {th }}$ November, 2017 Accepted: $20^{\text {th }}$ February, 2018 